ISSN.2621-9832

JURNAL MathEdu (MathematicEducationJournal) http://journal.ipts.ac.id/index.php/MathEdu

Vol. 4 . No. 3 November 2021

\title{
PENERAPAN MODEL PEMBELAJARAN BERBASIS MASALAH DENGAN BLENDED UNTUK MENINGKATKAN KEMAMPUAN PEMECAHAN MASALAH MATEMATIKA SISWA
}

\author{
Oleh : \\ *Rahima Safitra Pane ${ }^{1}$, Yuni Rhamayanti ${ }^{2}$, Haritsah Hammamah Harahap ${ }^{3}$ \\ Fakultas Keguruan dan Ilmu Pendidikan, Universitas Graha Nusantara Padangsidimpuan
}

\begin{abstract}
Abstrak
Jenis penelitian yang digunakan adalah Penelitian Tindakan Kelas (PTK) dengan menggunakan dua siklus pembelajaran, dengan subjek kelas X-1 SMA Negeri 1 Batangtoru yang berjumlah 25 orang. Sedangkan objek penelitian ini adalah penggunaan model pembelajaran berbasis masalah dengan Blended untuk meningkatkan kemampuan pemecahan masalah matematika siswa. Sebelum instrumen digunakan terlebih dahulu dilakukan uji coba tes untuk melihat validitas dan reabilitas tes. Dari 6 soal tes siklus I dan 6 soal tes siklus II yang diuji coba diperoleh 5 soal tes siklus I yang valid (sah) dan 5 soal tes siklus II yang valid (sah), dan semua soal tes reliable dengan koefisien reabilitas tes 0,926 dengan tingkat reliabilitas tinggi dan memiliki korelasi validasi dengan kategori sedang. Hasil rata-rata tes kemampuan pemecahan masalah matematika siswa pada tes kemampuan pemecahan masalah matematika siswa pada siklus I yaitu 68,80 pada kategori "Cukup" dengan ketuntasan 64,00\% dan persentase kadar aktivitas siswa 70,31\%. Kemudian melanjutkan kegiatan siklus II dimana rata-rata hasil tes kemampuan pemecahan masalah matematika siswa pada siklus II yaitu 83,04 pada kategori "Baik” dengan persentase ketuntasan 92,00\% dan persentase kadar aktivitas siswa $89,06 \%$.
\end{abstract}

Kata kunci-Kemampuan Pemecahan Masalah, Pembelajaran Berbasis Masalah dengan Blended, Sistem Persamaan Linear Dua Variabel.

Abstract
The type of research used is Classroom Action Research (CAR) using two learning cycles, with the subject of class X-1 SMA Negeri 1 Batangtoru totaling 25 people. While the object of this research is the use of problem-based learning model with Blended to improve students' mathematical problem solving ability. Before the instrument was used, a test trial was conducted to see the validity and reliability of the test. Of the 6 test questions in the first cycle and 6 test questions in the second cycle, 5 test questions in the first cycle were valid (valid) and 5 test questions in the second cycle were valid (valid), and all test questions were reliable with a test reliability coefficient of 0.926 with a level high reliability and has a validation correlation with the moderate category. The average result of the students' mathematical problem solving ability test on the students' mathematical problem solving ability test in the first cycle was 68.80 in the "Enough" category with $64.00 \%$ completeness and the percentage of student activity levels was $70.31 \%$. Then continue the activities of the second cycle where the average result of the students' mathematical problem solving ability test in the second cycle is 83.04 in the "Good" category with $92.00 \%$ completeness percentage and $89.06 \%$ student activity level percentage

Keywords - Problem Solving Ability, Blended Problem Based Learning, Two Variable Linear Equation System.

\section{PENDAHULUAN}

Salah satu tujuan pembelajaran matematika adalah agar peserta didik memiliki kemampuan memecahkan masalah yang meliputi kemampuan memahami masalah, merancang model matematika, menyelesaikan model dan menafsirkan solusi yang diperoleh (BSNP, 2006: 346). Tujuan tersebut menempatkan pemecahan masalah menjadi bagian dari kurikulum matematika yang sangat penting. Dalam proses pembelajaran maupun menyelesaikan masalah, siswa dapat memperoleh pengalaman menggunakan pengetahuan serta keterampilan yang sudah dimiliki. Pengalaman inilah yang kemudian melatih daya pikir siswa menjadi logis, analitis, sistematis, kritis, dan kreatif dalam menghadapi persoalan.

Melalui latihan memecahkan masalah, siswa akan belajar mengorganisasikan kemampuannya dalam menyusun strategi yang sesuai untuk menyelesaikan masalah. Pemecahan masalah mendorong siswa untuk mendekati masalah autentik, dunia nyata dengan cara sistematis (Jacobsen, Eggen, dan Kauchak, 2009: 255). Jika seorang siswa telah berlatih menyelesaikan masalah, maka dalam kehidupan nyata siswa itu akan mampu mengambil keputusan terhadap suatu masalah, sebab dia mempunyai keterampilan 
ISSN.2621-9832

JURNAL MathEdu (MathematicEducationJournal) http://journal.ipts.ac.id/index.php/MathEdu

Vol. 4 . No. 3 November 2021

mengumpulkan informasi yang relevan, menganalisis informasi, dan menyadari betapa perlunya meneliti kembali hasil yang telah diperoleh. Dalam serangkaian proses belajar mengajar di sekolah, kegiatan belajar mengajar merupakan kegiatan yang sangat penting, itu berarti berhasil atau tidaknya tujuan pencapaian pengajaran di sekolah banyak tergantung pada situasi kegiatan belajar mengajar yang dilaksanakan di dalam kelas.

Salah satu fenomena yang terjadi di kelas sewaktu pembelajaran matematika berlangsung ialah kurangnya kemampuan siswa dalam memecahkan masalah matematika yang diberikan oleh guru. Hal ini dikarenakan matematika merupakan salah satu mata pelajaran yang bersifat abstrak, materi yang dipelajari berbentuk nyata dan jika guru tidak memilih model pembelajaran yang tepat dan menguasai materi, maka hasil belajar siswa akan rendah.

Demikian juga kondisi yang sama dialami oleh siswa SMA Negeri 1 Batangtoru khususnya pada mata pelajaran matematika, yang diketahui setelah peneliti melakukan wawancara dengan salah seorang guru matematika di SMA Negeri 1 Batangtoru, yaitu Ibu Rosida Hesti, S.Pd, yang mengajar di kelas X, menyatakan bahwa salah satu kelemahan yang dialami siswa adalah kurangnya kemampuan pemecahan masalah matematika siswa dalam belajar matematika. Salah satu materi yang sulit dirasa oleh siswa adalah pokok bahasan Sistem Persamaan Linear Dua Variabel. Terutama dalam menyelesaikan soal-soal dalam bentuk pemecahan masalah, dan menghubungkannya dalam kehidupan sehari-hari. Selain wawancara, peneliti juga melakukan observasi. Dari hasil observasi yang peneliti lakukan di kelas X SMA Negeri 1 Batangtoru, diketahui bahwa metode pembelajaran yang dilaksanakan dalam proses belajar mengajar di kelas adalah model pembelajaran langsung.

Selama proses belajar mengajar berlangsung ada siswa yang tidak memperhatikan penjelasan dari guru, dan ada sebagian siswa yang tidak membawa buku paket/panduan. Pada saat guru memberi pertanyaan, siswa tidak mau menjawab jika tidak ditunjuk, dan siswa tidak ada yang bertanya apabila ada materi yang belum jelas.

Untuk memperkuat fakta yang terjadi di kelas, peneliti juga melakukan tes diagnostik kemampuan awal siswa pada pokok bahasan Sistem Persamaan Linear Dua Variabel kepada siswa kelas X SMA Negeri 1 Batangtoru. Dari jumlah semua siswa sebanyak 34 orang, hanya 8 orang yang mampu mengidentifikasi masalah yang meliputi unsur-unsur yang diketahui dan yang ditanyakan, 9 orang yang mampu membuat model matematika dari suatu masalah serta menuliskan cara yang digunakan dalam menyelesaikan soal, 7 orang yang mampu melakukan perhitungan yang di ukur dengan melaksanakan rencana yang sudah dibuat serta membuktikan bahwa langkah yang dipilih adalah benar, hanya 5 orang yang mampu memeriksa penyelesaian (mengetes atau menguji coba jawaban) atau memeriksa jawaban adakah yang kurang lengkap atau kurang jelas, dan 5 orang lainnya tidak menjawab sama sekali (jawaban kosong).

Berdasarkan uraian di atas terlihat jelas bahwa tingkat kemampuan sebagian siswa dalam memecahkan masalah matematika masih cukup rendah khususnya mata pelajaran matematika pada pokok bahasan Sistem Persamaan Linear Dua Variabel. Dan inilah salah satu bukti yang akurat bagi peneliti bahwasanya kemampuan pemecahan masalah matematika siswa Kelas X SMA Negeri 1 Batangtoru masih rendah.

Permasalahan lain yang peneliti temukan di kelas adalah kurangnya aktivitas siswa terhadap pembelajaran matematika selama proses belajar mengajar berlangsung. Guru terlihat lebih aktif, sementara siswa bersifat pasif. Siswa hanya menunggu dari guru tanpa ada usaha untuk menemukan sendiri pengetahuan, keterampilan dan sikap yang dibutuhkan. Dan aktivitas siswa yang sering dilakukan hanya mendengarkan, mencatat, dan mengerjakan soal individu saja. Siswa masih malu bertanya kepada guru jika mengalami kesulitan dalam memahami atau menyelesaikan soal yang diberikan. Mata pelajaran matematika pun masih dianggap sebagai mata pelajaran rumus. Tanpa perlu upaya pemecahan masalah dan dikaitkan dengan permasalahan dalam kehidupan sehari-hari. Kondisi di atas dapat terjadi kemungkinan disebabkan oleh pengajaran yang dilaksanakan oleh guru bidang studi matematika kurang bervariasi bagi pemahaman siswa terhadap materi pelajaran matematika, sehingga siswa tidak dapat memahami ataupun menguasai materi pelajaran yang disajikan.

Untuk menumbuhkembangkan kemampuan pemecahan masalah matematika siswa dalam pembelajaran matematika di sekolah, maka diperlukan upaya untuk memperbaiki masalah pembelajaran khususnya untuk meningkatkan kemampuan pemecahan masalah matematika siswa. Salah satu model pembelajaran yang dianggap peneliti tepat untuk meningkatkan kemampuan pemecahan masalah matematika siswa adalah dengan penerapan model pembelajaran berbasis masalah Dengan Blended.

Pembelajaran berbasis masalah melibatkan peserta didik dalam proses pembelajaran yang aktif, kolaboratif, berpusat kepada peserta didik, untuk mengembangkan keterampilan berfikir dan keterampilan memecahkan masalah.Pembelajaran berbasis masalah dimulai dengan pemberian masalah, masalah memiliki konteks dengan dunia nyata, siswa secara berkelompok aktif merumuskan masalah dan 
ISSN.2621-9832

JURNAL MathEdu (MathematicEducationJournal) http://journal.ipts.ac.id/index.php/MathEdu

Vol. 4 . No. 3 November 2021

mengidentifikasi kesenjangan pengetahuan mereka, mempelajari dan mencari sendiri materi yang terkait dengan masalah dan melaporkan solusi dari masalah. Dengan demikian, dalam pembelajaran berbasis masalah guru tidak menyajikan konsep matematika dalam bentuk yang sudah jadi, namun melalui kegiatan pemecahan masalah siswa digiring ke arah menemukan konsep sendiri.

Sedangkan Blended learning perpaduan yang baik antara pengalaman pembelajaran daring dan luring. Sehingga kekuatan atau kelebihan antara pembelajaran daring dan tatap muka dapat tercampur menjadi pengalaman belajar yang unik sesuai dengan tujuan pendidikan. Dengan demikian, siswa diharapkan memiliki kemampuan pemecahan masalah yang utuh dari sebuah materi yang diformulasikan dalam masalah, penguasaan sikap positif, dan keterampilan secara bertahap dan berkesinambungan.

Berdasarkan uraian di atas, maka penulis tertarik untuk mengadakan penelitian dengan judul : "Penerapan Model Pembelajaran Berbasis Masalah Dengan Blended Untuk Meningkatkan Kemampuan Pemecahan Masalah Matematika Siswa Kelas X-1 SMA Negeri 1 Batangtoru.

\section{METODE PENELITIAN}

Jenis penelitian ini merupakan Penelitian Tindakan Kelas. Penelitian tindakan kelas ini terdiri atas 2 siklus. Setiap siklus dilaksanakan sesuai dengan tujuan yang ingin dicapai, seperti yang didesain untuk meningkatkan kemampuan pemecahan masalah matematika siswa dan meningkatkan aktivitas belajar matematika siswa dengan melalui penerapan model Pembelajaran Berbasis Masalah dengan Blended.

Sebelum diberikan perlakuan, siswa diberi tes awal, selanjutnya diberikan perlakuan dengan menggunakan model pembelajaran berbasis masalah. Setelah diberi perlakuan, siswa kembali diberi tes pertama (hasil belajar siklus I). Selanjutnya tes hasil belajar siklus II, dan seterusnya jika permasalahan yang diteliti masih ada yang belum terselesaikan, maka dilanjutkan ke siklus berikutnya dengan memberikan perlakuan. Kemudian di bandingkan untuk setiap siklus, apakah perlakuan dapat meningkatkan kemampuan pemecahan masalah matematika siswa.

Tahap pelaksanaan tindakan kelas antara lain : 1) Perencanaan Tindakan, 2) Pelaksanaan Tindakan, 3) Observasi, dan 4) Refleksi.

Subjek penelitian ini adalah seluruh siswa kelas X-1 SMA Negeri 1 Batangtoru Tahun Ajaran 2020-2021 yang berjumlah 34 siswa. Dimana jumlah siswa laki-laki 14 orang dan jumlah siswa perempuan 20 orang.

Objek penelitian ini adalah penerapan model Pembelajaran Berbasis Masalah Dengan Blended untuk meningkatkan kemampuan pemecahan masalah matematika siswa pada pokok bahasan Sistem Persamaan Linear Dua Variabel.

Teknik analisis data adalah suatu kegiatan dalam mengklasifikasikan dan mengumpulkan data yang telah diperoleh. Dengan kata lain, teknik analisis data adalah cara yang dilakukan untuk mengolah data penelitian dalam mencapai tujuan penelitian. Menurut Sudjiono (2009: 274), "Teknik analisis data berkenaan dengan pengolahan data penelitan". Dalam hal ini suatu pekerjaan menyusun dan mengorganisasi data, membuat tabel-tabel data menurut masa-masanya, seperti: tabel distribusi frekuensi, tabel kontingensi. Bila diperlukan membuat diagram/grafik, seperti histogram, poligon, dan grafik".

Dengan demikian, teknik analisis data, adalah cara-cara yang dilakukan dalam penelitian untuk mengolah data dari sumber data. Sesuai dengan tujuan penelitian yang pada dasarnya ingin mengetahui hubungan kebiasaan membaca artikel dengan kemampuan menulis paragraf argumentasi oleh siswa, maka analisis data yang dipakai adalah analisis deskriptif teknik korelasional. Data yang diperoleh dari lapangan ditulis dalam bentuk uraian atau laporan terperinci. Data yang telah dikoreksi kemudian ditabulasikan ke dalam tabel untuk dapat dianalisis.

Dalam Penelitian Tindakan Kelas ini akan dilihat indikator kinerjanya siswa.

1. Tes : Rata-rata nilai tes kemampuan pemecahan masalah matematika siswa

2. Observasi : Aktivitas siswa selama proses pembelajaran berlangsung di kelas

Sebagai alat ukur keberhasilaan (Indikator Keberhasilan Penelitian Tindakan Kelas ini dapat dilihat dari:

1. Terdapat $80 \%$ dari jumlah siswa yang tingkat kemampuan pemecahan masalah matematika siswa minimal cukup dengan model pembelajaran berbasis masalah dengan Blended pada pokok bahasan Sistem Persamaan Linear Dua Variabel di kelas X-1 SMA Negeri 1 Batangtoru Tahun Ajaran 2020/2021.

2. Aktivitas siswa terhadap pembelajaran matematika pada pokok bahasan Sistem Persamaan Linear Dua Variabel meningkat dengan menerapkan model pembelajaran berbasis masalah dengan Blended yang ditandai dengan hasil observasi dengan persentasi $85 \%$. 


\section{HASIL DAN PEMBAHASAN}

\section{Deskripsi Hasil Penelitian Tindakan Kelas Siklus I}

Siklus I dilaksanakan dalam 2 kali pertemuan, dengan masing-masing pertemuan berlangsung selama 4 x 40 menit. Subjek penelitian adalah kelas X-1 SMA Negeri 1 Batangtoru yang berjumlah 25 orang siswa. Hasil penelitian tindakan siklus I diuraikan dalam beberapa tahapan. Adapun tahapan yang dilakukan dalam proses PTK (Penelitian Tindakan Kelas) dilaksanakan yaitu perencanaan tindakan, pelaksanaan tindakan, observasi dan refleksi. Hasil penelitian siklus I diuraikan sebagai berikut:

1. Hasil Tes Kemampuan Pemecahan Masalah Matematika Siswa

Pelaksanaan tindakan siklus I merupakan implementasi dari perencanaan yang disusun sebelumnya. Tindakan pada siklus ini merupakan usaha untuk meningkatkan kemampuan pemecahan masalah matematika siswa. Selain itu, tindakan ini juga berusaha untuk menjadikan proses pembelajaran berlangsung secara efektif, tingkat hasil belajar siswa dapat dilihat pada tabel berikut ini.

\section{Tabel 1}

Deskripsi Hasil Tes Kemampuan Pemecahan Masalah Matematika Siswa Siklus I

\begin{tabular}{lcccc}
\hline No & Tingkat Kemampuan & Jumlah Siswa & Presentase $(\%)$ & Kategori \\
\hline 1 & $90-100$ & 0 & 0,00 & Sangat Baik \\
\hline 2 & $80-89$ & 7 & 28,00 & Baik \\
\hline 3 & $65-79$ & 9 & 36,00 & Cukup \\
\hline 4 & $55-64$ & 6 & 24,00 & Kurang \\
\hline 5 & $0-54$ & 3 & 12,00 & Sangat Kurang \\
\hline & Total & 25 & 100 & - \\
\hline
\end{tabular}

Dari tabel diatas di peroleh bahwa tingkat kemampuan pemecahan masalah matematika siswa terhadap pokok bahasan persamaan linear dua variabel masih pada kategori "Cukup". Dari 25 siswa yang mengikuti tes tidak ada siswa yang memperoleh kategori "Sangat Baik" atau 0,00\%, yang memperoleh kategori "Baik" 7 orang atau 28,00\%, yang memperoleh kategori "Cukup" 9 orang atau 36,00\%, yang memperoleh kategori "Kurang" 6 orang atau 24,00\%, dan yang memperoleh kategori "Sangat Kurang" 3 orang atau 12,\%. Secara klasikal tingkat kemampuan pemecahan masalah matematika siswa yang memperoleh kategori "Cukup" 16 orang siswa dari 25 siswa yang mengikuti tes atau 64,00\%, sehingga belum sesuai dengan target yang telah ditetapkan $\geq 80 \%$ dan perlu dilakukan perbaikan pembelajaran yang mungkin dapat meningkatkan kemampuan pemecahan masalah matematika siswa. Maka diadakan refleksi untuk siklus berikutnya.

\section{Hasil Observasi Aktivitas Siswa}

Guru yang bertindak sebagai kolabolator mengamati guru yang bertindak sebagai guru PTK (Penelitian Tindakan Kelas) yang sedang mengajar di kelas dengan pokok bahasan persamaan linear dua variabel. Pelaksanaan dilakukan pada saat guru melaksanakan proses pembelajaran dengan model pembelajaran berbasis masalah dengan Blended untuk meningkatkan kemampuan pemecahan masalah matematika siswa. Observer memiliki peran mengamati dan memotret semua aktivitas siswa yang terjadi dikelas ketika tindakan dilakukan.

Adapun hasil pengamatan observer terhadap aktivitas siswa siklus I dalam pembelajaran matematika selama 2 kali pertemuan dapat dilihat pada tabel berikut:

Tabel 2

Kadar Aktivitas Siswa Siklus I

\begin{tabular}{|c|c|c|c|c|c|}
\hline \multirow[t]{2}{*}{ No. } & \multirow[t]{2}{*}{ Aspek Yang Diamati } & \multicolumn{2}{|c|}{$\begin{array}{l}\text { Kadar Aktivitas Siswa } \\
\text { Pertemuan }\end{array}$} & \multirow[t]{2}{*}{$\begin{array}{l}\text { Rata - } \\
\text { rata }\end{array}$} & \multirow[t]{2}{*}{$\begin{array}{l}\text { Persentase } \\
\quad(\%)\end{array}$} \\
\hline & & I & II & & \\
\hline 1 & Mendengarkan penjelasan dengan baik & 3 & 3 & 3,00 & 75,00 \\
\hline 2 & Antusias dalam belajar & 3 & 3 & 3,00 & 75,00 \\
\hline 3 & Bertanya kepada guru & 2 & 3 & 2,50 & 62,50 \\
\hline 4 & $\begin{array}{l}\text { Memperhatikan dan menanggapi } \\
\text { pertanyaan guru }\end{array}$ & 3 & 3 & 3,00 & 75,00 \\
\hline 5 & $\begin{array}{l}\text { Dapat menghubungkan materi } \\
\text { pelajaran yang sedang dipelajari }\end{array}$ & 2 & 3 & 2,50 & 62,50 \\
\hline
\end{tabular}


ISSN.2621-9832

JURNAL MathEdu (MathematicEducationJournal) http://journal.ipts.ac.id/index.php/MathEdu Vol. 4 . No. 3 November 2021

\begin{tabular}{|c|c|c|c|c|c|}
\hline & dengan materi pelajaran sebelumnya & & & & \\
\hline 6 & $\begin{array}{l}\text { Bertanya dan menanggapi pertanyaan } \\
\text { teman }\end{array}$ & 2 & 3 & 2,50 & 62,50 \\
\hline 7 & $\begin{array}{l}\text { Menyelesaikan tugas yang diberikan } \\
\text { guru }\end{array}$ & 3 & 3 & 3,00 & 75,00 \\
\hline 8 & $\begin{array}{l}\text { Merangkum pelajaran yang sedang } \\
\text { dipelajari }\end{array}$ & 3 & 3 & 3,00 & 75,00 \\
\hline & Persentase $(\%)$ & 65,63 & $\mathbf{7 5 , 0 0}$ & \multicolumn{2}{|c|}{$\mathbf{7 0 , 3 1}$} \\
\hline & Kualifikasi Nilai & (cukup) & (cukup) & \multicolumn{2}{|c|}{ (cukup) } \\
\hline
\end{tabular}

Dari tabel 2 dilihat dari kadar aktivitas siswa pada pertemuan I diperoleh persentase 65,63\% berada pada kategori "Cukup", dan pada pertemuan II diperoleh persentase 75,00\% berada pada kategori "Cukup". Dari persentase tersebut terlihat jelas ada peningkatan kadar aktivitas siswa pada pertemuan I dan pertemuan II. Akan tetapi jika dilihat dari rata-rata kadar aktivitas diperoleh 70,31\% berada kategori "Cukup", artinya kadar aktivitas siswa belum mencapai/memperoleh batas kriteria.

Dari tabel dan diagram aktivitas siswa siklus I di atas dapat dijelaskan persentase yang didapat pada pertemuan I dan II adalah 70,31\%, hal ini menunjukkan aktivitas siswa masih sangat kurang, belum sesuai dengan yang direncanakan dalam penelitian ini adalah $\geq 85 \%$.

Berdasarkan uraian di atas, terlihat aktivitas siswa belum terpenuhi dengan baik. Kriteria yang didapat masih sangat kurang, siswa belum terbiasa model pembelajaran berbasis masalah dengan Blended. Sehingga perlu tindak lanjut pada siklus II dengan upaya maksimal, agar aktivitas siswa meningkat.

\section{Deskripsi Hasil Penelitian Tindakan Kelas Siklus II}

Melihat hasil analisis dari penelitian tindakan kelas siklus I diperoleh hasil kemampuan pemecahan masalah matematika siswa yang masih jauh dari persentase yang diharapkan. Sejalan dengan hal tersebut, pelaksanaan model pembelajaran berbasis masalah dengan Blended belum terlaksana dengan baik. Untuk itu peneliti kembali melanjutkan penelitian pada siklus II dengan melaksanakan tahap yang sama seperti pada siklus I yaitu perencanaan tindakan, pelaksanaan tindakan, observasi dan refleksi.

\section{Hasil Tes Kemampuan Pemecahan Masalah Matematika Siswa}

Berdasarkan hasil tes siklus I diperoleh nilai kemampuan pemecahan masalah matematika siswa di bawah dari persentase yang diharapkan sehingga peneliti melanjutkan ke siklus II. Pada siklus II dilaksanakan penelitian kembali dengan melaksanakan pembelajaran matematika pada pokok bahasan persamaan linear dua variabel menggunakan model pembelajaran berbasis masalah dengan Blended, dimana pada akhir pertemuan diberikan tes kemampuan pemecahan masalah matematika siswa yang sebelumnya telah divalidasi. Adapun hasil tes kemampuan pemecahan masalah matematika siswa diuraikan pada tabel berikut:

Tabel 3

Deskripsi Hasil Tes Kemampuan Pemecahan Masalah Matematika Siswa Siklus II

\begin{tabular}{ccccc}
\hline No & Tingkat Kemampuan & Jumlah Siswa & Presentase $(\%)$ & Kategori \\
\hline 1 & $90-100$ & 5 & 20,00 & Sangat Baik \\
\hline 2 & $80-89$ & 10 & 40,00 & Baik \\
\hline 3 & $65-79$ & 8 & 32,00 & Cukup \\
\hline 4 & $55-64$ & 2 & 8,00 & Kurang \\
\hline 5 & $0-54$ & 0 & 0,00 & Sangat Kurang \\
\hline & Total & 25 & 100 & - \\
\hline
\end{tabular}

Dari tabel di atas diperoleh tingkat kemampuan pemecahan masalah matematika siswa pada pokok bahasan persamaan linear dua variabel meningkat dari hasil tes siklus I. Dari hasil tes kemampuan pemecahan masalah matematika siswa siklus II, yang memperoleh kategori "Sangat Baik" terdapat 5 siswa atau 20,00\%, yang memperoleh kategori "Baik" terdapat 10 siswa atau 40,00\%, yang memperoleh kategori "Cukup" terdapat 8 siswa atau 32,00\%, yang memperoleh kategori "Kurang" terdapat 2 siswa atau 8,00\%. Dan yang memperoleh kategori "Sangat Kurang" tidak ada siswa 0\%. Secara klasikal tingkat kemampuan pemecahan masalah matematika siswa yang memperoleh kategori "Cukup" 23 orang siswa dari 25 siswa yang mengikuti tes atau 92,00\%. Hal ini menunjukkan tingkat kemampuan pemecahan masalah matematika siswa meningkat dari "Kurang" menjadi "Cukup", dari "Cukup" menjadi "Baik", dari "Baik" menjadi "Sangat Baik".

Ini berarti tingkat kemampuan pemecahan masalah matematika siswa telah mencapai kriteria yang ditentukan yakni berada pada $\geq 80 \%$ dari seluruh siswa yang mengikuti tes. Berdasarkan hasil tersebut, 
ISSN.2621-9832

JURNAL MathEdu (MathematicEducationJournal) http://journal.ipts.ac.id/index.php/MathEdu

Vol. 4 . No. 3 November 2021

maka penelitian dihentikan pada siklus ini karena sudah memenuhi kriteria ataupun tujuan penelitian yang diharapkan, maka siklus ini berhenti pada siklus II.

\section{Hasil Observasi Aktivitas Siswa}

Adapun hasil pengamatan observer terhadap aktivitas siswa siklus II dalam pembelajaran matematika selama 2 kali pertemuan dapat dilihat pada tabel berikut:

Tabel 4

Kadar Aktivitas Siswa Siklus II

\begin{tabular}{|c|c|c|c|c|c|}
\hline \multirow[t]{2}{*}{ No. } & \multirow[t]{2}{*}{ Aspek Yang Diamati } & \multicolumn{2}{|c|}{$\begin{array}{l}\text { Kadar Aktivitas } \\
\text { Siswa Pertemuan }\end{array}$} & \multirow[t]{2}{*}{$\begin{array}{c}\text { Rata - } \\
\text { rata }\end{array}$} & \multirow[t]{2}{*}{ Persentase $(\%)$} \\
\hline & & I & II & & \\
\hline 1 & Mendengarkan penjelasan dengan baik & 3 & 4 & 3,50 & 87,50 \\
\hline 2 & Antusias dalam belajar & 4 & 4 & 4,00 & 100,00 \\
\hline 3 & Bertanya kepada guru & 3 & 3 & 6,00 & 75,00 \\
\hline 4 & $\begin{array}{l}\text { Memperhatikan dan menanggapi pertanyaan } \\
\text { guru }\end{array}$ & 3 & 4 & 3,50 & 87,50 \\
\hline 5 & $\begin{array}{l}\text { Dapat menghubungkan materi pelajaran yang } \\
\text { sedang dipelajari dengan materi pelajaran } \\
\text { sebelumnya }\end{array}$ & 3 & 3 & 3,00 & 75,00 \\
\hline 6 & Bertanya dan menanggapi pertanyaan teman & 4 & 4 & 4,00 & 100,00 \\
\hline 7 & Menyelesaikan tugas yang diberikan guru & 4 & 4 & 4,00 & 100,00 \\
\hline 8 & Merangkum pelajaran yang sedang dipelajari & 3 & 4 & 3,50 & 87,50 \\
\hline & Persentase $(\%)$ & 84,38 & $\mathbf{9 3 , 7 5}$ & & 89,06 \\
\hline & Kualifikasi Nilai & (baik) & $\begin{array}{c}\text { (sangat } \\
\text { baik) }\end{array}$ & & ngat baik) \\
\hline
\end{tabular}

Dari tabel di atas aktivitas siswa siklus II di atas dapat dijelaskan persentase yang didapat pada pertemuan I dan II adalah $89,06 \%$, hal ini menunjukkan aktivitas siswa telah mencapai kriteria yang direncanakan dalam penelitian ini adalah $\geq 85 \%$. Peningkatan kadar aktivitas siswa menunjukkan bahwa penerapan model pembelajaran berbasis masalah dengan Blended telah terlaksana dengan baik dan sesuai dengan langkah-langkah yang telah ditetapkan pada model pembelajaran berbasis masalah dengan Blended. Sejalan dengan peningkatan kemampuan pemecahan masalah matematika siswa, kadar aktivitas siswa juga mengalami peningkatan. Hal ini membuktikan bahwa model pembelajaran berbasis masalah dengan Blended baik untuk diterapkan karena mampu meningkatkan aktivitas belajar siswa.

Berdasarkan uraian di atas, terlihat jelas bahwa aktivitas siswa telah terpenuhi dengan baik. Kriteria yang didapat telah tercapai, artinya model pembelajaran berbasis masalah dengan Blended terlaksana dengan baik. Sehingga tidak perlu tindak lanjut lagi. Berdasarkan hasil tersbut maka penelitian untuk observasi siswa telah dapat dihentikan.

\section{KESIMPULAN}

Berdasarkan tujuan penelitian, hasil penelitian dan pembahasan, maka penelitian yang dilaksanakan di Kelas X-1 SMA Negeri 1 Batangtoru dapat disimpulkan sebagai berikut:

1. Model pembelajaran berbasis masalah dengan Blended dapat meningkatkan kemampuan pemecahan masalah matematika siswa pada pokok bahasan Persamaan Linear Dua Variabel di kelas X-1 SMA Negeri 1 Batangtoru Tahun Ajaran 2020-2021. Dapat dilihat dari hasil tes kemampuan pemecahan masalah matematika siswa pada hasil tes siklus I 64,00\% sedangkan siklus II 92,00\% terdapat peningkatan sebesar $28,00 \%$ dan menunjukkan bahwa hasil yang diperoleh telah terpenuhi dengan kriteria yang diharapkan yaitu $\geq 80 \%$.

2. Aktivitas siswa meningkat melalui penerapan model pembelajaran berbasis masalah dengan Blended. Hal ini dapat dilihat dari hasil observasi aktivitas siswa siklus I 70,31\% sedangkan siklus II 89,06\% terdapat peningkatan sebesar $18,75 \%$ dan menunjukkan bahwa hasil yang diperoleh telah terpenuhi dengan kriteria yang diharapkan yaitu $\geq 85 \%$. 


\section{REFERENSI}

Arikunto, Suharsimi, 2009, Manajemen Penelitian. Jakarta: PT Rineka Cipta.

Branca, 1994, Nida dan Fitri, 2008, Kemampuan Pemecahan Masalah. Jakarta: Bumi Aksara.

Darsono, 2011, Ciri - Ciri Belajar. Jakarta: PT Rineka Cipta.

Dewey, 2009, Pembelajaran Berbasis Masalah. Surabaya: Unesa University Press.

Dierich, D. Paul, 2011, Aktivitas - Aktivitas Belajar. Jakarta: PT Rineka Cipta.

Dimiyati, 2009, Aktivitas - Aktivitas Belajar. Jakarta: PT Rineka Cipta.

Djamarah, Syaiful Bahri, (2011), Psikologi Belajar, Jakarta: Rineka Cipta.

Hamzah, 2009, Hakikat Belajar Matematika. Jakarta: PT Rineka Cipta.

Ibrahim, M. dan Nur, M. 2000. Pembelajaran Berbasis Masalah. Surabaya: Unesa University Press. Jacobsen, Eggen, dan Kauchak, 2009, Kemampuan Pemecahan Masalah. Jakarta: PT Rineka Cipta. Purwantoro, Eko, 2005, Manajemen Penelitian. Jakarta: PT Rineka Cipta.

Rusman, 2010, Model - Model Pembelajaran, Jakarta: Bumi Aksara.

Rustam \& Mundilarto, 2004, Penelitian Tindakan Kelas. Yogyakarta: Rajawali Pers.

Sanjaya, 2008, Pembelajaran Berbasis Masalah. Jakarta: Bumi Aksara.

Slameto, 2010, Belajar dan Pembelajaran. Jakarta: PT Rineka Cipta.

Suhardjono, 2007, Penelitian Tindakan Kelas. Yogyakarta: Pustaka Belajar.

Syah, Muhibbin, 2008, Belajar dan Pembelajaran. Jakarta: PT Rineka Cipta. 